\title{
Lung function in Lancashire cotton and man made fibre spinning mill operatives
}

\author{
David Fishwick, Angela M Fletcher, C Anthony C Pickering, Robert McL Niven, \\ E Brian Faragher
}

\begin{abstract}
Objectives-This survey was conducted to investigate current lung function levels in operatives working with cotton and man made fibres. Dust concentrations, smoking history, and occupational details were recorded so that factors influencing lung function could be identified.
\end{abstract}

Methods-A cross sectional study of respiratory symptoms and lung function was made in 1057 textile spinning operatives of white caucasian extraction. This represented $96.9 \%$ of the total available working population to be studied. Most (713) worked currently with cotton. The remainder worked with man made fibre.

Lung function was assessed by measuring forced expiratory volume in one second $\left(F E V_{1}\right)$ and forced vital capacity (FVC). Exposure to cotton dust was measured in the work area and personal breathing zones, and retrospective exposure to cotton dust over a working life was estimated with accurate work history and best available hygiene data.

Results-3.5\% of all operatives had byssinosis, $55(5 \cdot 3 \%)$ chronic bronchitis, 36 (3.5\%) work related persistent cough, 55 $(5 \cdot 3 \%)$ non-byssinotic work related chest tightness, and $56(5 \cdot 3 \%)$ work related wheeze. A total of 212 static work area dust samples (range $0 \cdot 04-3.23 \mathrm{mg} / \mathrm{m}^{3}$ ) and 213 personal breathing zone samples (range 0.14-24.95 $\mathrm{mg} / \mathrm{m}^{3}$ ) were collected. Percentage of predicted FEV 1 was reduced in current smokers (mean 89.5, 95\% confidence interval (95\% CI) 88-91) in comparison with non-smokers $(93 \cdot 1$, 90.5-94.1) and FVC was reduced in operatives currently working with man made fibre $(95 \cdot 3,93.8-96.9)$ in comparison with cotton $(97 \cdot 8,96 \cdot 6-99 \cdot 0)$. Regression analysis identified smoking $(P<0 \cdot 01)$, increasing age $(P<0 \cdot 01)$, increasing time worked in the waste room $(P<0 \cdot 01)$, and male sex $(P<0.05)$ as being associated with a lower FEV $_{1}$ and FVC. Current and retrospective cotton dust exposures did not appear as predictor variables in the regression analysis although in a univariate analysis, $\mathrm{FEV}_{1}$ was reduced in those operatives exposed to high dust concentrations assessed by personal and work area sampling.

Discussion-This study has documented loss of lung function in association with exposure to cotton dust. Those operatives with work related symptoms had signifi- cantly lower FEV 1 and FVC than asymptomatic workers. Although lung function seemed to be affected by high dust exposures when operatives were stratified into high and low exposure groups, regression analysis did not identify current dust concentrations as an independent factor influencing loss. Smoking habit was found to explain most of the measured change in FEV 1 and FVC. It is likely that smoking and dust exposure interact to cause loss of lung function in cotton textile workers.

(Occup Environ Med 1996;53:46-50)

Keywords: byssinosis; lung function; cotton dust

Byssinosis is a respiratory disease primarily associated with workplace exposure to cotton dust characterised by chest tightness that is worse on the first day of exposure to cotton dust after a break from work. Despite early references to the disease known commonly today as byssinosis, ${ }^{12}$ it was to be almost 100 years before serious epidemiological work was undertaken both in the Lancashire cotton mills and in mills throughout the other cotton producing countries of the world. ${ }^{34}$ The most recent study of this population has estimated the current prevalence of byssinosis to be $3.6 \% .^{5}$ This seems to be falling in comparison with earlier papers. ${ }^{3}$

This cross sectional study was performed to document the prevalences of work related respiratory symptoms in current textile workers and to associate them with dust exposures and measured lung function.

\section{Methods}

A cross sectional analysis of respiratory symptoms and lung function was made at 11 spinning mills in Lancashire. Two of these processed man made fibre, one a mix of cotton and man made fibre and the remaining eight processed cotton alone. These comprised a total consenting population of 360 man made fibre operatives and 730 cotton operatives. Of the possible population $97 \%$ took part from varying work areas in a standard spinning mill. Table 1 summarises the work areas. Table 2 shows details of mean age, smoking habits, and sex distribution for each mill. The respiratory questionnaire was modified from an MRC version designed to identify byssinosis, chronic bronchitis, work related wheeze, and cough. ${ }^{6}$ Non-byssinotic chest tightness is 
Table 1 Occupational codings

\begin{aligned} & \hline 1 Blow room, opening room operatives \\ & 2 Card attendant \\ & 3 Draw, speed frame tenters and combers \\ & 4 Card room supervisors and instructors \\ & 5 Other card room operatives \\ & 6 Spinners \\ & 7 Doffers \\ & 8 Spinning supervisors and instructors \\ & 9 Other spinning room operatives \\ & 10 Winders \\ & 11 Winding room supervisors and instructors \\ & 12 Other winding room operatives \\ & 13 Managerial staff \\ & 14 Warehouse staff \\ & 15 All areas \\ & 16 Waste room operatives \\ & 17 Open end mill main work area \\ & \hline\end{aligned}

shown as a separate category to byssinosis as some operatives complained of chest tightness that improved on rest days but did not conform to the classic definition of byssinosisthat is, worse on the first working day. "Work related" was defined as any symptom improving on rest days or volunteered as being worse at work.

A full work history including current and previous rooms of work, fibre type used, and use of respiratory protection was recorded to place operatives into occupational groups. Operatives were defined by their current position and most tended to keep to a particular occupation for many years.

A full smoking history was also recorded. For the purpose of analysis, operatives have been divided into current smokers and a combined category for ex and never smokers. A cumulative estimate of lifetime cigarette, cigar, and tobacco consumption has also been used (pack-years).

\section{LUNG FUNCTION ASSESSMENT}

Each operative was asked to perform a reproducible forced expiratory volume in one second $\left(\mathrm{FEV}_{1}\right)$ and a forced vital capacity (FVC) (greatest value of three values within 5\%). A single dry wedge spirometer (Vitalograph, Bucks, UK) was used for the entire study and measurements were made by one of two investigators (DF and $\mathrm{AMF}$ ). The $\mathrm{FEV}_{1}$ and FVC were then converted to percentages of predicted values for further analysis with prediction equations, ${ }^{7}$ based on a non-smoking healthy European working population. Percentages of predicted values have been used as these were thought to be the most easily manipulated, understood, and most clinically relevant to investigating textile workers. Only those operatives of white caucasian extraction have been used in subsequent analysis.

Table 2 Personal characteristics and smoking habits by mill of work

\begin{tabular}{cclll}
\hline Mill & \multicolumn{1}{l}{$n$} & Mean age $(y)$ & Men (\%) & Current smokers (\%) \\
\hline 1 & 58 & 42 & 83 & 47 \\
2 & 132 & 44 & 79 & 42 \\
3 & 85 & 42 & 77 & 53 \\
4 & 51 & 42 & 86 & 56 \\
5 & 61 & 37 & 73 & 59 \\
6 & 138 & 33 & 61 & 58 \\
$7^{\star}$ & 151 & 37 & 62 & 51 \\
$8^{\star}$ & 193 & 31 & 65 & 49 \\
9 & 56 & 38 & 92 & 49 \\
10 & 32 & 39 & 92 & 51 \\
$11^{\star \star}$ & 86 & 37 & 61 & \\
\hline
\end{tabular}

${ }^{\star}$ Man made fibre mill; ${ }^{\star \star}$ man made fibre and cotton blend mill.
COTTON DUST SAMPLING

This was performed in the work area by static L60 samplers (Rothero and Mitchell, Negretti Automation, Aylesbury, Bucks, UK) according to guidelines set down in the $\mathrm{EH} 25$ directive from the United Kingdom Health and Safety Executive ${ }^{8}$ and as described in a previous publication from this centre. ${ }^{5}$

Personal breathing zone cotton dust concentrations were assessed in nine of the 11 cotton mills with the Institute of Occupational Medicine dust sampling head already described recently by our group. ${ }^{9}$

Operatives were each ascribed a static work area dust concentration to serve as an estimate of their current cotton dust exposure and were placed into occupational sets to group operatives with similar occupations or cotton dust exposures. All man made fibre operatives were given a zero value. All values of current exposure were expressed in $\mathrm{mg} / \mathrm{m}^{3}$ of total dust less fly.

Each operative was also assigned a personal cotton dust concentration in $\mathrm{mg} / \mathrm{m}^{3}$ (except mill 2 as this closed before the dust sampling exercise).

A measure was also made of cumulative lifetime exposure to cotton dust. The method, previously described, ${ }^{5}$ used current dust exposures in the work area, work history, and known and estimated previous dust concentrations at each mill in the study. Cumulative exposure of dust was calculated by adding together individual exposures in each position at each mill while being blinded to the current work area and number of symptoms.

\section{STATISTICAL METHODS}

Lung function indices are presented as percentage predicted value for each operative (percentage of predicted FEV ${ }_{1}\left(\mathrm{PPFEV}_{1}\right)$, percentage of predicted FVC (PPFVC)). Means of these and the $95 \%$ confidence intervals (95\% CIs) are used to compare lung function between symptom and dust exposure groups. Statistical significance was set at the conventional 5\% level.

\section{REGRESSION ANALYSIS}

Forward stepwise analyses were performed to identify those factors independently influencing the level of current lung function and to estimate the relative magnitudes of their effects. Percentages of predicted $\mathrm{FEV}_{1}$ and FVC were in turn tested against a variety of potential predictor variables including age, sex, current and previous workrooms, the three variables of exposure to cotton dust (present and past exposure, and personal dust) and smoking data. For each lung function variable, the order in which significant factors entered the equation is indicated along with the corresponding $\mathbf{P}$ and cumulative $\mathrm{R}^{2}$ values.

\section{Results}

THE STUDY POPULATION

A total of 1057 operatives out of a possible $1090(97 \%)$ took part in the study. Those who refused to take part in this study were of similar 
Table 3 Lung function results for operatives with and without byssinosis, across all fibre types

\begin{tabular}{|c|c|c|}
\hline Symptoms & $\begin{array}{l}\text { PPFEV } \\
\text { Mean (SD) 95\% CI }\end{array}$ & $\begin{array}{l}\text { PPFVC } \\
\text { Mean (SD) } 95 \% C I\end{array}$ \\
\hline $\begin{array}{l}\text { Byssinosis }(n=36) \\
\text { No byssinosis }(n=1008) \\
\text { Chronic bronchitis }(n=55) \\
\text { No bronchitis }(n=953) \\
\text { Non-byssinotic chet tightness }(n=55) \\
\text { No non-byssinotic chest tightness }(n=953) \\
\text { Work related wheeze }(n=56) \\
\text { No work related wheeze }(n=952) \\
\text { Work related cough }(n=36) \\
\text { No work related cough }(n=972)\end{array}$ & 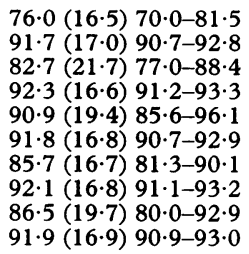 & $\begin{array}{l}85 \cdot 2(13 \cdot 7) 80 \cdot 1-89 \cdot 7 \\
97 \cdot 4(15 \cdot 8) 96 \cdot 4-98 \cdot 4 \\
90 \cdot 8(17 \cdot 3) 85 \cdot 5-96 \cdot 2 \\
97 \cdot 8(15 \cdot 3) 96 \cdot 8-98 \cdot 4 \\
97 \cdot 5(19 \cdot 3) 92 \cdot 5-102 \cdot 0 \\
97 \cdot 4(15 \cdot 5) 96 \cdot 6-98 \cdot 4 \\
93 \cdot 4(15 \cdot 2) 89 \cdot 5-97 \cdot 4 \\
97 \cdot 6(15 \cdot 8) 96 \cdot 6-98 \cdot 6 \\
96 \cdot 2(16 \cdot 0) 90 \cdot 9-101 \cdot 0 \\
97 \cdot 5(15 \cdot 7) 96.5-98 \cdot 4\end{array}$ \\
\hline
\end{tabular}

Table 4 Lung function and fibre type.

\begin{tabular}{lll}
\hline & $\begin{array}{l}\text { PPFEV } \\
\text { Mean }(95 \% \text { CI })\end{array}$ & $\begin{array}{l}\text { PPFVC } \\
\text { Mean }(95 \% \text { CI })\end{array}$ \\
\hline Cotton operatives & $91 \cdot 3(90 \cdot 2-92 \cdot 8)$ & $97 \cdot 8(96 \cdot 6-99 \cdot 0)$ \\
Man made fibre & $90 \cdot 6(88 \cdot 8-92 \cdot 3)$ & $95 \cdot 3(93 \cdot 8-96 \cdot 9)$ \\
\hline
\end{tabular}

Table 5 Current static cotton dust concentration and current personal dust exposure ranges ( $\left.\mathrm{mg} / \mathrm{m}^{3}\right)$

\begin{tabular}{rll}
\hline Mill & $\begin{array}{l}\text { Current static cotton } \\
\text { dust concentration range }(n)\end{array}$ & $\begin{array}{l}\text { Current personal dust } \\
\text { exposure range }(n)\end{array}$ \\
\hline 1 & $0 \cdot 15-3 \cdot 23(28)$ & $0 \cdot 25-16 \cdot 71(39)$ \\
3 & $0 \cdot 30-2 \cdot 36(26)$ & $0 \cdot 35-8 \cdot 94(25)$ \\
4 & $0 \cdot 12-0 \cdot 71(20)$ & $0 \cdot 17-8 \cdot 32(14)$ \\
5 & $0 \cdot 21-2 \cdot 94(26)$ & $0 \cdot 61-22 \cdot 79(22)$ \\
6 & $0 \cdot 23-1 \cdot 89(28)$ & $0 \cdot 48-6 \cdot 03(30)$ \\
8 & $0 \cdot 06-0 \cdot 35(19)$ & $0 \cdot 24-2 \cdot 02(20)$ \\
84 & $0 \cdot 04-0 \cdot 37(6)$ & $0 \cdot 73-17 \cdot 32(7)$ \\
9 & $0 \cdot 34-1 \cdot 80(19)$ & $0 \cdot 56-24 \cdot 95(15)$ \\
10 & $0 \cdot 10-2 \cdot 39(20)$ & $0 \cdot 88-16 \cdot 28(10)$ \\
11 & $0 \cdot 04-0 \cdot 28(20)$ & $0 \cdot 14-2 \cdot 23(31)$ \\
\hline
\end{tabular}

age to those studied and from a range of work areas. Of all operatives $36(3.5 \%)$ had symptoms of byssinosis, $55(5.3 \%)$ chronic bronchitis, $36(3.5 \%)$ work related persistent cough, $55(5 \cdot 3 \%)$ non-byssinotic chest tightness, and $56(5 \cdot 3 \%)$ work related wheeze.

\section{LUNG FUNCTION ANALYSIS}

Reproducible lung function data were available on $1043(98.7 \%)$ of a total study population of 1057 operatives. There was no reason to suspect that the operatives who refused to be studied were significantly more impaired than those who agreed. There were small but significant differences in measured lung function between the sexes; mean (95\% CI) PPFEV $_{1}$ in women $92.3(90 \cdot 5-94.1)$ and in men 90.6 (89.3-91.9), and similarly for PPFVC in women $98.2(96.5-99.9)$ and in men $96 \cdot 4(95 \cdot 2-97 \cdot 5)$.

The PPFEV 1 was lower in current smokers (mean 89.5, 95\% CI 88-91) than in ex and non-smokers (mean 93·1, 95\% CI 90·5-94·1). The PPFVC did not differ between smoking categories.

Table 3 contains lung function data about byssinosis, chronic bronchitis, non-byssinotic chest tightness, work related wheeze, and persistent work related cough. Operatives with byssinosis, chronic bronchitis, and work related wheeze had significant impairment of their lung function compared with operatives without these symptoms.

Mean $\mathrm{PPFEV}_{1}$ did not differ between operatives currently working with either cotton or man made fibres and PPFVC was significantly less in workers with man made fibres than in cotton workers (table 4).

Table 5 shows the numbers of dust samples collected and their range at each mill studied and the differences between sampling techniques and between different mills.

Table 6 shows the univariate relation between current lung function in those operatives exposed to either low or high current dust concentrations as assessed by current static work area and personal zone exposures. In each case the $\mathrm{FEV}_{1}$ and FVC were lower in the high exposure group.

Regression analysis identified a measure of smoking, increasing age, increasing total time worked in the waste room (a traditionally dusty area), and being male as being associated with a lower PPFEV $_{1}$ and PPFVC. Tables 7 and 8 show the corresponding regression results. Regression analysis did not identify past exposure as an independent variable associated with loss of lung function. Mean $(95 \%$ CI ) past exposure values (per year worked with cotton) were $0.74(0.70-0.77)$ $\mathrm{mg} / \mathrm{m}^{3}$ in those with a PPFEV ${ }_{1}$ of $90 \%$ or less in comparison with $0.71(0.68-0.74)$ for those with $\mathrm{PPFEV}_{1}$ greater than $90 \%$.

\section{Discussion}

Both acute, shift related effects ${ }^{10}$ and chronic, accelerated lung volume loss ${ }^{11}$ associated with cotton dust exposure are described in the literature. The design of this study did not enable us to measure across shift changes and measurements were made as near the beginning of each shift as possible to attempt to reduce any "acute" effect of cotton dust exposure. Lung function data were available in most of the operatives in this study. Fourteen operatives either refused to have the investigation performed for varying reasons or were unable to produce a satisfactory reproducible spirometric curve.

In this study, female operatives were found

Table 6 Comparison of PPFEV in low and high exposure groups

\begin{tabular}{|c|c|c|c|c|}
\hline & \multicolumn{2}{|l|}{ Current static cotton dust } & \multicolumn{2}{|l|}{ Current personal dust } \\
\hline & $\begin{array}{l}\text { High exposure } \\
\left(>0.5 \mathrm{mg} / \mathrm{m}^{3}\right) \\
\text { Mean }(S D) 95 \% \mathrm{CI}\end{array}$ & $\begin{array}{l}\text { Low exposure } \\
\left(<0.5 \mathrm{mg} / \mathrm{m}^{3}\right) \\
\text { Mean }(S D) 95 \% \mathrm{CI}\end{array}$ & $\begin{array}{l}\text { High exposure } \\
\left(>0.5 \mathrm{mg} / \mathrm{m}^{3}\right) \\
\text { Mean }(S D) 95 \% \mathrm{CI}\end{array}$ & $\begin{array}{l}\text { Low exposure } \\
\left(<0 \cdot 5 \mathrm{mg} / \mathrm{m}^{3}\right) \\
\text { Mean }(S D) 95 \% \mathrm{CI}\end{array}$ \\
\hline $\begin{array}{l}\text { n } \\
\text { PPFEV }_{1}\end{array}$ & $\begin{array}{l}432 \\
90 \cdot 1(17 \cdot 7) 88 \cdot 5-91 \cdot 7\end{array}$ & $\begin{array}{l}611 \\
92 \cdot 0(16.9) 90 \cdot 6-93.3\end{array}$ & $\begin{array}{l}263 \\
90 \cdot 4(16 \cdot 9) 88 \cdot 3-92 \cdot 4\end{array}$ & $\begin{array}{l}497 \\
92 \cdot 8(17 \cdot 0) 91 \cdot 2-94 \cdot 2\end{array}$ \\
\hline
\end{tabular}


Table 7 Regression analysis results for PPFEV, as the dependent variable

\begin{tabular}{|c|c|c|c|c|c|}
\hline $\begin{array}{l}\text { Predictor } \\
\text { variable }\end{array}$ & Estimate & $S E M$ & $R^{2}$ value & $P$ value & $f$ \\
\hline Smoking (pack-years) & -0.0110 & 0.0021 & $6 \cdot 34$ & $<0.01$ & $70 \cdot 6$ \\
\hline Age & -0.2399 & 0.04246 & $8 \cdot 67$ & $<0.01$ & $26 \cdot 5$ \\
\hline Duration in waste room (y) & -1.012 & 0.3596 & $9 \cdot 37$ & $<0.01$ & $8 \cdot 1$ \\
\hline \multicolumn{6}{|l|}{ Cotton grade: } \\
\hline 1 & $100 \cdot 3$ & $1 \cdot 646$ & & & \\
\hline 3 & $108 \cdot 2$ & $2 \cdot 282$ & & & \\
\hline 5 & $98 \cdot 56$ & 1.921 & $11 \cdot 15$ & $<0.01$ & $5 \cdot 2$ \\
\hline 6 & $102 \cdot 4$ & $1 \cdot 837$ & & & \\
\hline 8 & $102 \cdot 7$ & $2 \cdot 326$ & & & \\
\hline Sex & $2 \cdot 398$ & $1 \cdot 101$ & $11 \cdot 56$ & $<0.05$ & $4 \cdot 75$ \\
\hline
\end{tabular}

Table 8 Regression analysis results for PPFVC as the dependent variable

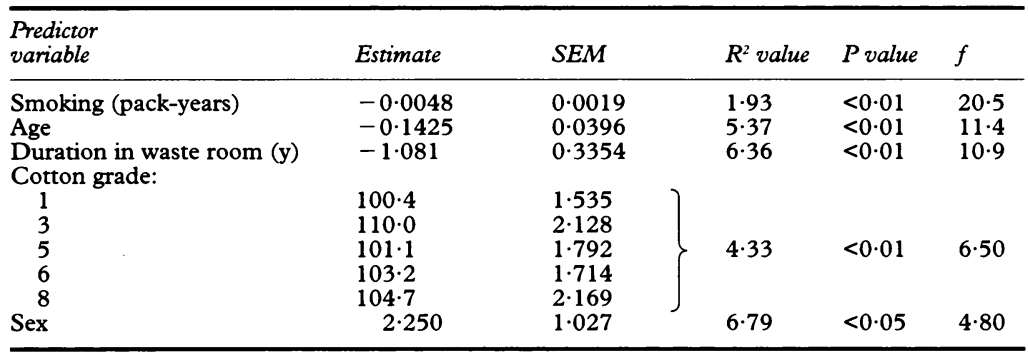

to have significantly greater $\mathrm{PPFEV}_{1}$ and PPFVC, both with univariate analysis and regression. Early epidemiological work tended not to comment on differences between men and women as most dusty occupations were carried out by men. Subsequent studies have, however, identified some sex differences. ${ }^{12} 13$ Elwood et $a l^{14}$ also documented less loss of lung function over time in women who smoked than in men who smoked. This paper also suggested other possible reasons for the observed reduction in lung function of cotton workers with particular reference to social circumstances, nutrition, and their reduced height. The differences in this study were small and probably of no clinical significance.

The effect of respiratory symptoms on lung function, other than those of byssinosis, were also considered in this study. Except for byssinosis, there is a paucity of epidemiological information in previous studies on symptoms and their associated physiological abnormalities.

Operatives without byssinosis who complained of work related wheeze had a lower PPFEV $_{1}$ and PPFVC than those without this symptom. Some of these people volunteered the fact that they had asthma and that the work environment made the wheeze worse. It is possible that a proportion of these people were workers with pre-existing asthma that tended to be exacerbated at work. A proportion, however, had become wheezy as a consequence of their work with cotton and the significance of this remains obscure as these people seemed not to have had byssinotic symptoms. A possibility is that some people become sensitised to a particular agent at work and have developed a form of occupational asthma discrete from the condition byssinosis.
One of the long term purposes of this study is to consider this issue.

Operatives with non-byssinotic work related chest tightness and work related cough did not seem to have notably impaired lung function compared with operatives without this additional symptom. This tends to imply that significant airflow obstruction was not the cause of these symptoms, although the lung function assessment was made only on one occasion and consequently did not reflect physiological changes when the symptom was being experienced nor did it enable conclusions to be drawn about falls in $\mathrm{FEV}_{1}$ in these people during a shift.

Chronic bronchitis was a commonly reported symptom in those with byssinosis and also an isolated symptom. As early as 1955 , Schilling et al noted a smaller loss in lung volumes in cotton workers with chronic bronchitis than in byssinotic workers. In this study, there was a large overlap between byssinosis and chronic bronchitis, with $20 \%$ of all byssinotic workers complaining of work related phlegm production on a regular basis compared with a background rate in all other operatives of about $5 \% .{ }^{15}$ This reaffirms the original concept suggested by Massoud et al of two distinct forms of byssinosis; pure byssinosis and byssinotic symptoms with chronic bronchitis. ${ }^{16}$

Schilling and Lond described early experiences in assessment of lung function in byssinotic workers. ${ }^{17}$ They documented diminished maximum voluntary ventilation in grade one and two byssinotic workers compared with control subjects from local Lancashire engineering firms. Belin et al compared $\mathrm{FEV}_{0.75}$ /body height ratio measurements from 15 byssinotic workers with a non-byssinotic control population of prisoners. ${ }^{18}$ The byssinotic values were notably lower. These data are difficult to interpret as smoking data were not recorded. Beck et al and Zuskin et al similarly documented that byssinotic workers had lower mean $\mathrm{FEV}_{1} \mathrm{~s}$ than non-byssinotic workers. ${ }^{13} 19$

The PPFEV 1 and PPFVC were lower in smokers compared with non-smokers across all fibre groups, and the regression analysis ranked smoking pack-years as the strongest predictor variable for both $\mathrm{PPFEV}_{1}$ and PPFVC. The exact relation between smoking and lung function abnormalities in the presence of exposure to cotton dust remains controversial. Early epidemiological studies tended not to include information on smoking habit. Merchant et al documented decrement in lung function in smokers compared with non-smokers, although men who smoked and had occupations exposed lightly to dust had significantly better lung function than those in heavily exposed occupations. ${ }^{12}$ Their subsequent work indicated that smoking and dust exposure may act independently to influence loss in lung volume. ${ }^{20}$ Imbus concluded that smoking was far more important than dust exposure in causing loss of $\mathrm{FEV}_{1}{ }^{21}$ When dust exposure was considered in this study, division of operatives into high and low exposures seemed to suggest an effect of current expo- 
sure on measured lung function. The regression analysis, however, did not identify a relation between current or past dust measurements and lung function. This is contrary to the findings of Jones et al who studied lung function variables in cotton operatives and man made fibre control workers. ${ }^{22}$ Mill of work, current dust concentrations, and occupation had no bearing on impairment of $\mathrm{FEV}_{1}$ and FVC although an association was found between increased duration of exposure to cotton dust and impaired FVC.

Beck et al suggested that the effects of dust and cigarette smoke may both have an independent role in influencing loss of lung function. ${ }^{23}$ They compared 477 cotton textile workers with 932 non-exposed controls. Cotton workers were found to have significantly lower FEV ${ }_{1}$ and FVC. The authors postulated that smoking and dust may have differential discrete actions on the smaller and larger airways, respectively; the combination of which led to the clinical syndrome of byssinosis.

The present study identified a function of cotton grade and a measure of duration of exposure to a known dirty environment as significant, although smoking pack-years was the most significant predictor of reduced lung function. Whether this finding indicates that there is a particular agent or quality of cotton dust within the waste area that causes accelerated loss of lung function is unknown and this study, due to its limitation as a cross sectional analysis, cannot add to this intriguing point.

In this study there did not seem to be an obvious effect of fibre type. In fact, mean PPFVC was significantly greater in cotton than in man made fibre mills. This paradoxical decrement in workers of man made fibre has previously been documented. ${ }^{12}$ The cause for this finding is not fully understood, but may represent the converse of the healthy worker effect in that operatives who cannot tolerate the cotton exposure, possibly with pre-existing lung disease, may move into a similarly skilled occupation in a man made fibre process.

It was intriguing to find that the $\mathrm{FEV}_{1}$ was significantly reduced from predicted values in asymptomatic operatives both in cotton and man made fibre mills. It is difficult to assume that this was due to a subclinical effect of cotton dust on the airways as it occurred equally in operatives exposed to man made fibre. It may, more likely, reflect the relatively high proportion of current smokers in both fibre groups.

In summary, this cross sectional study has documented reduced lung function associated with workplace exposure to cotton dust. Operatives with byssinosis, chronic bronchitis, and work related wheeze had significantly impaired lung function compared with operatives without these symptoms. Women operatives and those working with man made fibres or blends seemed to have less impairment of measured lung function. Regression analysis identified smoking, however, as the most significant single determinant of a reduced $\mathrm{FEV}_{1}$ and FVC although the duration of cotton exposure in the waste room did enter into the prediction for loss in $\mathrm{FEV}_{1}$ and FVC. The likely situation is that smoking and dust exposure interact in a complicated manner to augment the loss in lung volume.

This study was supported by grants from the Cotton Industry War Memorial Trust, the British Cotton Growers Association, Work Peoples Collection fund, Cotton Incorporated, and the Cotton Foundation, USA.

1 Zuskin E, Wolfson RL, Harpel G, Welborn JW, Bouhuys A. Byssinosis in carding and spinning workers. Arch A. Byssinosis in carding and
Environ Health 1969;19:666-73.

2 Molyneux MKB, Tombleson JBL. An epidemiological study of respiratory symptoms in Lancashire mills 1963-6. Br F Ind Med 1970;27:225-34.

3 Cinkotai FF, Rigby A, Pickering CAC, Seaborn D, Faragher E. Recent trends in the prevalence of byssinotic symptoms in the Lancashire textile industry. $\mathrm{Br} \mathcal{F}$ Ind Med 1988;45:782-9.

4 Lammers B, Schilling RSF, Walford J. A study of byssinosis, chronic respiratory symptoms, and ventilation capacity in English and Dutch cotton workers with special reference to atmospheric pollution. $\mathrm{Br} F$ Ind $\mathrm{Med}$
1964;21:124-34.

5 Fishwick D, Fletcher AM, Pickering CAC, Niven R McL, Faragher EB. Lung function, bronchial reactivity, atopic status and dust exposure in Lancashire cotton mill operastatus and dust exposure in Lancashire cotton
tives. Am Rev Respir Dis 1992;145:1103-8.

6 Committee on Research into Chronic Bronchitis. Questionnaire in respiratory symptoms and instructions for its use. London: Medical Research Council,1966.

7 Quanjer $P$, ed. Standardised lung function testing (Report of the working party on standardisation of lung function tests). Bull Eur Physiopathol Respir 1983;19(suppl 5): 45-5i.

8 Health and Safety Executive. Guidance note EH25, cotton dust sampling. London: HSE 1980.

9 Niven McL, Fishwick D, Pickering CAC, Fletcher AM, Warburton CJ, Crank P. A study of the performance and comparability of the sampling response to cotton dust of work area and personal sampling techniques. Ann Occup work area and personal

10 Jones RN, Butcher BT, Hammad YY, Diem JE, Glindmeyer HW, Lehrer SB, et al. Interaction of atopy and exposure to cotton dust in the bronchoconstrictor response. Br $\mathcal{F}$ Ind Med 1980;37:141-6.

11 Schachter EN, Maunder LR, Beck GJ. The pattern of lung function abnormalities in cotton textile workers. $\mathrm{Am} \mathrm{Rev}$ Respir Dis 1984;129:523-7.

12 Merchant JA, Kilburn KH, O'Fallon WM, Hamilton JD, Lumsden JC. Byssinosis and chronic bronchitis among cotton textile workers. Ann Intern Med 1972;76:423-33.

13 Beck GJ, Schachter EN, Maunder LR, Schilling RSF. A
prospective study of chronic lung disease in cotton textile workers. Ann Intern Med 1982;97:645-51.

14 Elwood PC, Sweetnam PM, Bevan C, Saunders MJ. Respiratory disability in ex-cotton workers. Br $\mathcal{F}$ Ind Med Respiratory disa

15 Schilling RSF, Hughes JPW, Dingwall-Fordyce I, Gilson JC. An epidemiological study of byssinosis among Lancashire cotton workers. $B r f$ Ind Med 1955;12: 217-27.

16 Massoud AAE, Altounyan REC, Howell JBL, Lane RE. Effects of histamine aerosol in byssinotic subjects. $\mathrm{Br} \mathscr{F}$ Ind Med 1967;24:38-40.

17 Schilling RSF, Lond MD. Byssinosis in cotton and othe textile workers. Lancet 1956;ii:261-5, and 319-25.

18 Belin L, Bouhuys A, Hoekstra W, Johansson MB, Lindel SE, Pool J. Byssinosis in cardroom workers in Swedish cotton mills. Br f Ind Med 1965;22:101.

19 Zuskin E, Valic F, Butkovic D, Bouhuys A. Lung function in textile workers. Br $\mathcal{F}$ Ind Med 1975;32:283-8.

20 Merchant JA, Lumsden JC, Kilburn KH, O'Fallon WM, Ujda JR, Germino VH, Hamilton JD. Dose response studies in cotton.

21 Imbus H. Cotton dust. Am Ind Hyg Assoc $\mathcal{F}$ 1986;47:712-6.

22 Jones $\mathrm{RN}$, Diem JE, Glindmeyer $\mathrm{H}$, Dharmarajan $\mathrm{V}$, Hammad YY, Carr J, Weill H. Mill effect and dose response relationship in byssinosis. $\mathrm{Br} f$ Ind $\mathrm{Med}$
1979;36:305-13. 1979;36:305-13.

23 Beck GJ, Maunder LR, Schachter EN. Cotton dust and smoking effects on lung function in cotton textile workers. Am $\mathcal{F}$ Epidemiol 1984;119:33-43. 